\title{
Recombinant Human 6Ckine
}

National Cancer Institute

\section{Source}

National Cancer Institute. Recombinant Human 6Ckine. NCI Thesaurus. Code C1792.

A therapeutic recombinant analogue of a member of the endogenous CC chemokines

with potential antineoplastic activity. Expressed by various lymphoid tissues, endogenous 6Ckine is chemotactic for B and T lymphocytes and dendritic cells. 